\title{
Proses Penalaran Analogi Siswa Impulsif Dalam Memecahkan Masalah Bangun Ruang Sisi Lengkung
}

\author{
Diyah Ayu Rizki Pradita $^{1}$, Dwiyana ${ }^{1}$, Sisworo $^{1}$ \\ ${ }^{1}$ Pendidikan Matematika-Universitas Negeri Malang
}

\begin{tabular}{l}
\hline \hline INFO ARTIKEL \\
\hline Riwayat Artikel: \\
Diterima: $10-05-2019$ \\
Disetujui: 09-12-2019 \\
\hline
\end{tabular}

\section{Kata kunci:}

analogy reasoning; impulsive students; build curved side spaces; penalaran analogi; siswa impulsif; bangun ruang sisi lengkung

\begin{abstract}
ABSTRAK
Abstract: The aim of the study was to describe the process of reasoning analogy of students impulsive in solving problems in constructing build arches. This type of research is a qualitative descriptive study using Sternberg's stage. The subjects in this study were three students of class $X$. The instruments used were MFFT, TKM, TPABRSL, and interview guidelines. The results of indicate that impulsive students are highly capable and are able to pass the encoding and inferring stages. However, students who are capable are not doing the mapping and applying stages correctly. Whereas low-ability impulsive students cannot pass all stages.

Abstrak: Tujuan penelitian adalah menggambarkan proses penalaran analogi siswa impulsif dalam memecahkan masalah bangun ruang sisi lengkung. Jenis penelitian ini merupakan penelitian deskriptif kualitatif dengan menggunakan tahapan penalaran analogi menurut Sternberg. Subjek dalam penelitian ini adalah tiga siswa kelas X. Instrumen yang digunakan adalah tes MFFT, tes kemampuan matematika, tes penalaran analogi bangun ruang sisi lengkung (TPABRSL) dan pedoman wawancara. Hasil dari TPABRSL menunjukkan bahwa siswa impulsif berkemampuan tinggi dan sedang mampu melewati tahap encoding dan inferring. Akan tetapi, siswa berkemampuan sedang tidak melakukan tahap mapping dan tahap applying dengan benar, sedangkan siswa impulsif berkemampuan rendah tidak mampu melewati seluruh tahapan.
\end{abstract}

\author{
Alamat Korespondensi: \\ Diyah ayu Rizki Pradita \\ Pendidikan Matematika \\ Universitas Negeri Malang \\ Jalan Semarang 5 Malang \\ E-mail: dhitaarizki@gmail.com
}

Pendidikan merupakan salah satu alat untuk meningkatkan taraf kehidupan bangsa. Pada dasarnya, pendidikan merupakan sebuah upaya untuk meningkatkan kualitas sumber daya manusia yang dapat ditempuh salah satunya di bangku sekolah. Mata pelajaran yang wajib dipelajari siswa mulai jenjang dasar hingga perguruan tinggi yaitu matematika. Penguasaan matematika sejak dini diperlukan untuk dapat menguasai dan mencipta teknologi di masa depan (BSNP, 2008). Selain itu, tujuan pembelajaran matematika membantu siswa dalam menggunakan kemampuan bernalar pada pola dan sifat, mampu membuat generalisasi pada saat melakukan manipulasi matematika. NCTM (2000) juga menjelaskan bahwa standar proses pembelajaran matematika, meliputi pemecahan masalah, penalaran dan pembuktian, koneksi, komunikasi, dan representasi. Hal tersebut dikarenakan penalaran merupakan salah satu kemampuan yang menjadi target dalam pembelajaran matematika.

Herbert (2009) menjelaskan penalaran digambarkan untuk memikirkan hal yang logis dalam bertindak, seperti menganalisis, membuktikan, mengevaluasi, menjelaskan, membenarkan, menyimpulkan, dan membuat generalisasi pada diskusi matematika. Menurut pemikiran (Mikrayanti, 2012) menyebutkan penalaran sebagai kegiatan menyimpulkan argumen yang dihasilkan melalui langkah-langkah tertentu berdasarkan prinsip-prinsip yang telah diakui kebenarannya sebagai upaya memperlihatkan hubungan dua hal atau lebih. Salah satu variansi penalaran yang dapat digunakan untuk bernalar adalah dengan menggunakan penalaran matematis.

Mofidi, dkk. (2012) menjelaskan bahwa penalaran matematis secara garis besar dibagi menjadi tiga, yaitu penalaran induktif, penalaran deduktif, dan penalaran analogi. Penalaran induktif merupakan proses kegiatan bernalar dari aturan-aturan atau hal-hal yang mempunyai ketentuan bersifat khusus untuk diturunkan menjadi sebuah kesimpulan yang bersifat umum. Penalaran deduktif adalah proses kegiatan bernalar yang diperoleh dari pengetahuan-pengetahuan yang bersifat umum untuk diturunkan menjadi hal-hal yang bersifat khusus, sedangkan penalaran analogi adalah proses kegiatan bernalar yang dihasilkan dari kesamaan dua hal atau lebih dan memahami konsep yang baru dikaitkan dengan konsep matematika yang dimiliki sebelumnya. Dalam penelitian ini, peneliti akan fokus pada penalaran analogi siswa karena penalaran analogi memegang peranan penting untuk membentuk kemampuan matematis siswa. 
Mason (1994) menyatakan bahwa berpikir dengan menggunakan prinsip analogi akan memungkinkan siswa untuk menghasilkan pembelajaran yang lebih bermakna. Penelitian lain juga banyak yang menyoroti kekuatan analogi dalam menghubungkan informasi dan struktur pengetahuan yang lebih komprehensif dan terintegrasi. Dengan memperhatikan hubungan antara dua hal yang berbeda akan memunculkan keterampilan berpikir sesuatu hal yang baru. Lailiyah, dkk. (2017) menjelaskan bahwa dapat penalaran analogi diartikan sebagai aktivitas bernalar yang didasarkan dari adanya kesamaan prinsip berdasarkan hasil identifikasi dari domain yang dikenal (sumber) ke domain yang kurang dikenal (target) yang digunakan dalam memecahkan masalah. Gentner (dalam Romadlona, dkk., 2018) menyatakan bahwa "analogical thinking is ubiquitous in human cognition" yang dapat diartikan bahwa penalaran analogi pada dasarnya akan terdapat pada kognisi manusia sehingga akan memudahkan manusia untuk memecahkan masalah. Komponen penalaran analogi menurut (Sternberg, 1977) menyebutkan ada empat yaitu pengkodean (encoding), Menduga (inferring), Menghubungkan (mapping), dan Menerapkan (applying).

Berbicara tentang kemampuan pemecahan masalah, Rozencwajg (2003) menjelaskan bahwa dalam kegiatan pembelajaran apabila penalaran analogi yang dimiliki oleh siswa masih rendah, maka akan berpengaruh terhadap kemampuan pemecahan masalah. Lemahnya kemampuan penalaran matematika siswa yang dapat dicermati melalui The Programme For International Assesment (PISA, 2015) melaporkan bahwa nilai rata-rata matematika di Indonesia hanya mencapai 386. Nilai yang dicapai siswa jauh lebih rendah dibandingakan dengan beberapa negara lain di kawasan asia, seperti Singapura (564), Jepang (532), Korea (524), dan Vietnam (495).

Callejo \& Vila (2009) menjelaskan suatu masalah akan mudah dipecahkan dengan menghubungkan data yang tidak diketahui dan data yang sudah diketahui kesimpulannya sehingga dapat mengukur kemampuan matematika khusunya dalam hal penalaran yang dimiliki siswa. Suatu permasalahan dalam pembelajaran matematika, misalnya diberikan pada beberapa individu, maka akan mendapatkan respons atau tanggapan yang berbeda dalam memecahkannya. Perbedaan cara memecahkan tersebut disebabkan setiap individu memiliki keunikan dalam dirinya termasuk pada kemampuan matematis siswa. Perbedaan tersebut juga dapat dipengaruhi oleh karakteristik yang dimiliki oleh siswa yang berbeda-beda, termasuk dalam bernalar analogi. Salah satu karakteristik tersebut adalah gaya kognitif.

Chrysostomou, dkk (2013) menyatakan bahwa gaya kognitif dapat digambarkan sebagai metode yang disukai siswa untuk memahami, berpikir, dan mempertahankan informasi. Gaya kognitif secara spesifik dapat dilihat dari kebiasaan seseorang atau ciri khasnya dalam memahami, mengingat, berpikir, dan memecahkan masalah. Rahman (2018) menjelaskan bahwa (1) perbedaan kognitif secara psikologis, meliputi gaya kognitif field dependent dan field independent, (2) perbedaan gaya kognitif secara konseptual tempo, meliputi gaya kognitif reflektif dan impulsif, dan (3) perbedaan gaya kognitif berdasarkan cara berpikir, meliputi gaya kognitif intuitif-induktif dan logis deduktif.

Adapun dipilihnya subjek dalam penelitian yaitu siswa reflektif dan impulsif karena selama peneliti melakukan observasi awal, peneliti mengamati siswa yang memiliki ciri-ciri dari gaya kognitif reflektif dan impusif karena memang cenderung mudah dikenali dalam pembelajaran. Rozencwajg \& Corroyer (2005) juga menyatakan bahwa 70\% frekuensi siswa di dalam suatu kelas terdiri dari mayoritas siswa reflektif dan impulsif dibandingkan dengan gaya kognitif yang lain. Penelitian ini akan berfokus pada siswa impulsif. Pengklasifikasian gaya kognitif impulsif dapat diperhatikan dari dua aspek penting yaitu waktu dan ketepatan dalam membuat keputusan. Pemberian masalah pada siswa nantinya akan dijadikan sebagai sebuah tantangan agar dapat dipecahkan dan memungkinkan siswa menjadi lebih analitik dalam mengambil sebuah keputusan melalui beberapa langkah menyelesaikan masalah serta dapat menerapkan dalam kehidupan sehari-hari. Salah satunya pada materi geometri.

Ozerem (2012) menjelaskan bahwa pembelajaran materi geometri penting untuk diberikan di sekolah karena untuk membantu siswa belajar menganalisis dan menafsirkan dunia tempat mereka tinggal. Geometri merupakan satu diantara materi matematika di sekolah yang memiliki ruang lingkup yang luas. Secara garis besar, geometri digolongkan menjadi dua macam, yaitu bangun datar dan bangun ruang. Bangun ruang dalam geometri terdiri dari bangun ruang sisi datar dan bangun ruang sisi lengkung. Hasil ujian nasional tahun 2014/2015 menunjukkan bahwa daya serap siswa pada pokok bahasan geometri. Lemahnya siswa dalam menyerap materi geometri khususnya bangun ruang sisi lengkung terindikasi dari akibat pengetahuan yang dimiliki siswa masih terbatas dan kurangnya pengalaman dalam menggunakan penalaran analogi. Berdasarkan dasar pemikiran diatas, maka perlu dilakukan penelitian dengan judul "Proses Penalaran Analogi Siswa Impulsif dalam Memecahkan Masalah Bangun Ruang Sisi Lengkung”.

\section{METODE}

Fokus masalah dalam penelitian adalah identifikasi proses penggunaan penalaran analogi serta faktor yang memengaruhinya pada kelas X SMA Islam Sabilurrosyad Malang. Agar peneliti dapat mendeskripsikan secara jelas, rinci, dan mampu mendapatkan data yang mendalam dan akurat, maka penelitian ini menggunakan pendekatan deskriptif kualitatif. Dipilihnya penelitian deskriptif kualitatif pada dasarnya merupakan cara ilmiah untuk mendapatkan data dengan tujuan dan kegunaan tertentu, metode ini juga menyajikan secara langsung hakikat hubungan peneliti dan informan sehingga metode ini lebih peka dan dapat menyesuaikan diri dengan banyak penajaman pengaruh bersama terhadap nilai-nilai yang dihadapi (Moleong, 2011). 
Pemilihan subjek penelitian menggunakan teknik purposive sampling dengan prosedur awal pemilihan subjek penelitian yaitu memilih siswa kelas X SMA Islam Sabilurrosyad Malang berdasarkan gaya kognitif impulsif dan kemampuan matematis. Gaya kognitif impulsif diperoleh dari tes Matching Familiar Figure test (MFFT), selanjutnya diberikan tes kemampuan matematika. Kemudian subjek dipilih dengan bantuan pertimbangan dari guru matematika terkait kemampuan komunikasi dari subjek. Subjek yang sudah ditetapkan kemudian diberikan tes penalaran analogi. Tes penalaran analogi merupakan tes yang berisi tentang masalah yang dapat menggali lebih dalam penggunaan empat tahapan penalaran analogi yaitu encoding, inferring, mapping, dan applying dengan indikator pada tahapan tersebut sebagai berikut.

Pertama, Mengidentifikasi ciri-ciri atau struktur dari masalah sumber dan masalah target. Kedua, mencari hubungan untuk memecahkan masalah yang terdapat pada masalah sumber. Ketiga, mencari kesamaan hubungan antara masalah sumber dan masalah target dan membuat kesimpulan dari kesamaan serta mampu menjelaskan analogi yang terjadi. Keempat, memecahkan masalah pada masalah target dengan menggunakan cara atau konsep yang sama dengan masalah sumber. Hasil tes tersebut selanjutnya dianalisis. Kemudian dilakukan triangulasi data dengan melakukan wawancara kepada setiap subjek penelitian. Berikut soal tes penalaran analogi yang akan diujikan (Gambar 1).

Pak Yudi memiliki tiga tangki air berbentuk tabung dengan salah satunya berisi benda berbentuk kerucut. Jika diketahui tinggi tangki air II adalah dua kali tinggi tangki air I, Ukuran tangki air I sama dengan tangki air III, Luas alas Kerucut $=1,54 \mathrm{~m}$, dan Keliling $\mathrm{ABCD}=12,4 \mathrm{~m}$. Maka tentukan:

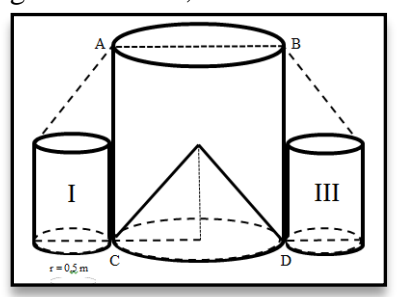

Jumlah tali minimal yang dapat digunakan untuk mengikat ketiga tangki air tersebut secara tepat dengan memutar melewati diameter tangki II!

\section{Gambar 1. Soal TPABRSL}

\section{HASIL}

Tes MFFT diikuti oleh 27 siswa. Berdasarkan hasil pengategorian, 13 siswa termasuk kategori gaya kognitif reflektif, delapan siswa termasuk kategori gaya kognitif impulsif, dan enam siswa tidak termasuk kategori gaya kognitif reflektif dan impulsif. Setelah peneliti menategorikan gaya kognitif tersebut, selanjutnya peneliti memberikan tes kemampuan matematika guna memperoleh subjek penelitian. Peneliti mengambil tiga subjek penelitian berdasarkan kategori gaya kognitif impulsif dengan kamampuan matematika tinggi, sedang, dan rendah. Setelah peneliti memperoleh subjek yang sesuai kemudian peneliti memberikan TPABRSL. Subjek tersebut diberikan kode S1 untuk subjek pertama (gaya kognitif impulsif dengan kemampuan tinggi), kode S2 untuk subjek kedua (gaya kognitif impulsif dengan kemampuan sedang), dan kode S3 untuk subjek ketiga (gaya kognitif impulsif dengan kemampuan rendah). Berikut ini gambaran hasil jawaban yang diperoleh $\mathrm{S} 1$ setelah mengerjakan TPABRSL.

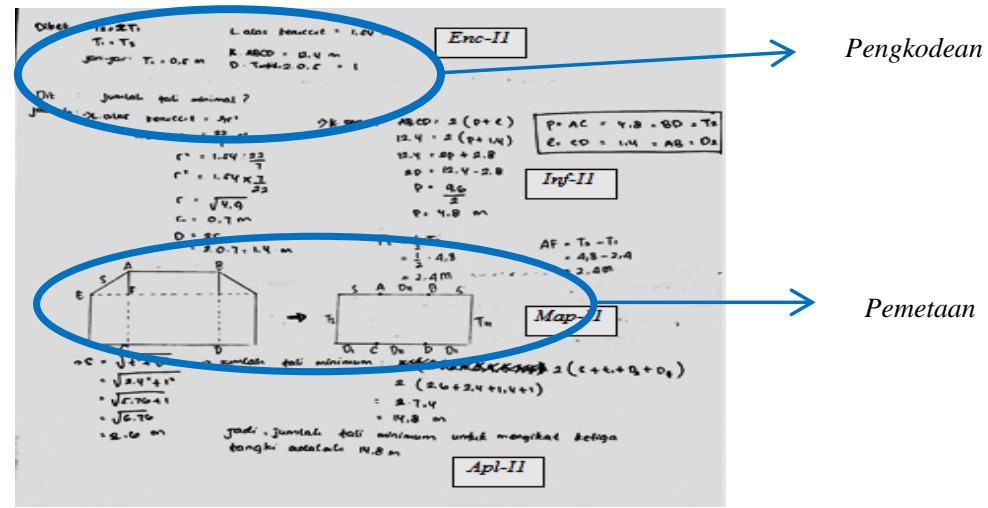

Gambar 2. Hasil Pekerjaan1 TPABRSL S1 
S1 dalam menyelesaikan soal TPABRSL yang diberikan dengan melakukan identifikasi masalah dengan cara menstruktur hal yang telah diketahui pada soal tersebut sehingga siswa disimpulkan dapat melakukan tahap encoding dengan baik. Selanjutnya setelah melakukan pengkodean, S1 menyimpulkan solusi masalah sumber dengan langkah awal membuat aturan penyelesaian dengan konsep keliling segiempat yang diperoleh informasinya ketika dalam sesi wawancara, hal ini menandakan S1 mampu melewati tahap inferring. Berikut hasil cuplikan wawancara:

DI (peneliti): "Tetapi mengapa di jawaban ada tulisan k-persegi ABCD? Berarti ABCD sisinya sama?"

S1: "Salah kak yang benar itu keliling segiempat kalau dari gambarnya seperti persegi panjang”.

Dengan hasil kesimpulan tersebut, kemudian S1 menghubungkan hubungan antara masalah sumber dengan masalah target yang ditandai dengan kode Map-II pada Gambar.1. Dengan demikian, S1 melewati tahap mapping (pemetaan). Kemudian untuk tahap applying diperoleh dari hasil pemetaan selanjutnya S1 menerapkan aturan penyelesaian dengan menemukan ukuran tali minimal dengan konsep keliling persegi panjang yang dapat dilihat paada kode Apl-II pada gambar 1 di atas. Beralih pada subjek yang kedua dimulai dengan mengerjakan seperti gambar 3.

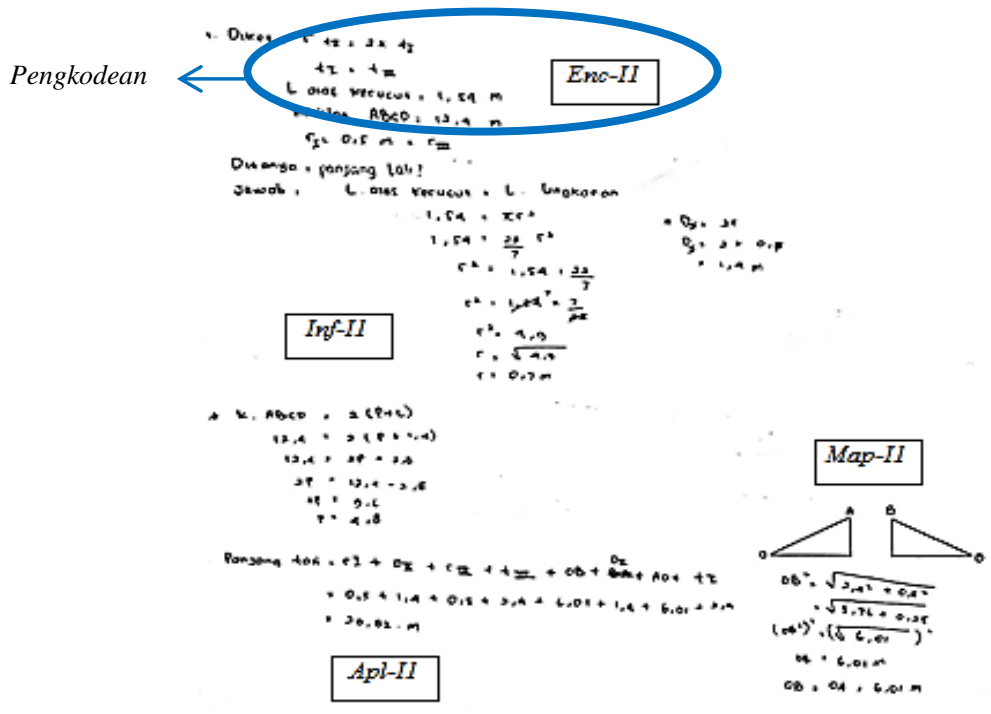

\section{Gambar 3. Hasil Pekerjaan 1 TPABRSL S2}

Tahapan encoding yang dilakukan S2 dalam menyelesaikan soal TPABRSL yang diberikan dimulai dengan menuliskan dan memahami hal yang telah diketahui pada soal. Hal tersebut mengartikan bahwa S2 sudah mampu melewati proses tersebut. Pada tahap inferring, S2 juga telah mampu menyimpulkan dugaan sementara bahwa soal tersebut menyerupai konsep segiempat yang mana dapat terlihat dari hasil jawaban siswa yang mulai mengarahkannya kepada konsep tersebut. Namun dari hasil kesimpulan yang telah dibuat, siswa S2 tidak dapat menyimpulkan pencarian hubungan antara masalah sumber dan masalah target, hal ini menandakan bahwa S2 tidak mampu melewati komponen mapping dengan baik. Kemudian pada tahap applying S2 tidak dapat melakukan penyelesaian karena adanya ketidaktepatan dalam memilih solusi penyelesaian seperti gambar di atas terjadinya ketidaktepatan terlihat kesalahan S2 dalam memasukkan hasil pengkodean yang telah dilakukan. Berikut hasil ketidaktepatan pekerjaan S2 dalam menyelesaikan soal (Gambar 4).

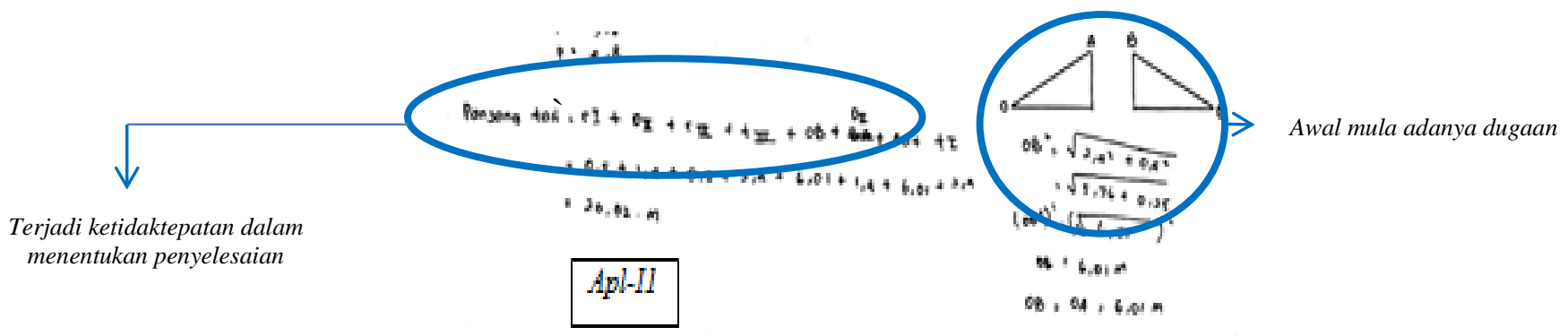

Gambar 4. Hasil Pekerjaan2 TPABRSL S2 
Identifikasi proses penalaran analogi yang selanjutnya dari S3 akan digambarkan di bawah ini. Berikut ini diperlihatkan hasil jawaban yang diperoleh S3 setelah mengerjakan TPABRSL

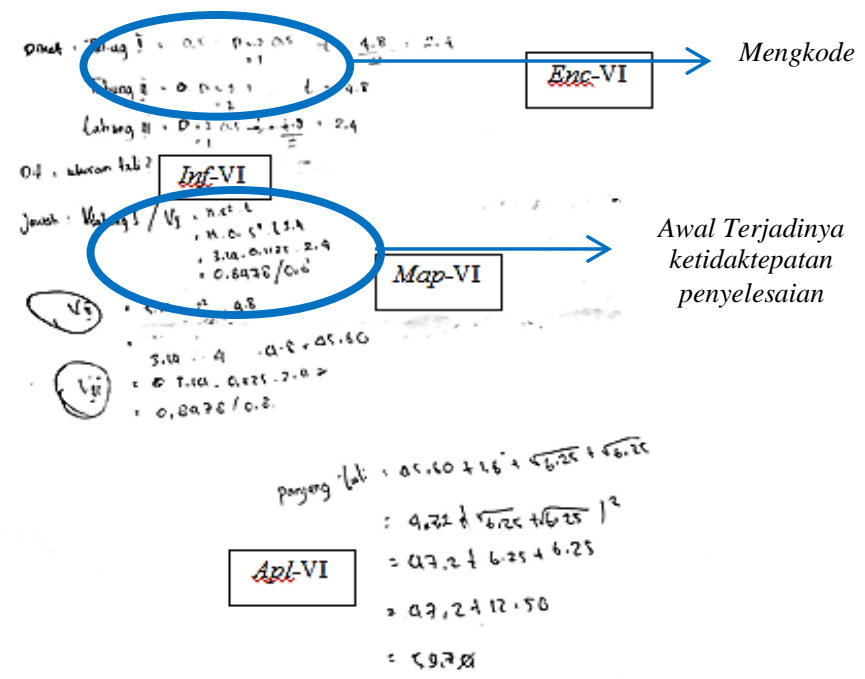

\section{Gambar 5. Hasil Pekerjaan TPABRSL Siswa S3}

Dari gambar yang telah dimunculkan, S3 memulai mengode dengan menyebutkan hal yang telah diketahui dan diminta pada soal, akan tetapi S3 hanya menuliskan angka yang terdapat pada gambar soal saja dengan memberikan pertanyaan yang penting untuk dituliskan hal yang diketahui pada gambar. Berikut hasil cuplikan wawancara:

DI (Peneliti): "Mengapa yang kamu tuliskan yang diketahui dari gambar pada soal saja?"

S3: "Iya kak soalnya yang penting untuk dituliskan dan menjadi kunci itu angka yang terdapat pada gambar dan angka yang diketahui pada kalimat dan angka pada soal ada yang tidak terpakai dan menjebak biasanya".

Selanjutnya metode penyelesaian memakai rumus yang tidak tepat yaitu volume tabung. Namun. S3 menentukan ukuran tali dengan menjumlah variabel yang ada, tetapi pada proses memasukkan variabelnya S3 tampak sedikit kesulitan sehingga menuliskan hal yang tidak diketahui sebelumnya yang dapat dilihat pada kode Apl-VI. Dari hasil pengerjaan dan sesi wawancara, peneliti memberikan kesimpulan bahwa S3 tidak dapat menganalogikan tes penalaran analogi yang diberikan, berbeda halnya S1 dan S2 yang dapat melakukan proses penalaran analogi dengan baik, meskipun S2 tidak melakukannya dengan sempurna serta tidak melakukan proses mapping dan applying dengan tepat.

\section{PEMBAHASAN}

Analisis data yang telah dipaparkan di atas, dapat terlihat bahwa S2 dan S3 tidak dapat melakukan penalaran analogi dengan baik. S2 dapat melewati tahap encoding (mengkode) dan tahap inferring (menyimpulkan) dengan tepat. Akan tetapi, ketika memasuki komponen mapping, S2 mengerjakan dengan tidak tepat salah satunya memunculkan kode OA dan OB dengan perhitungan yang kurang tepat. Salah satu penyebab terjadinya kesalahan dalam memetakan dan menerapkan hasil penyelesaian disebabkan karena S2 tidak memandang unsur secara detail. Hal tersebut sesuai dengan pendapat (Pang, dkk., 2009) yang menjelaskan bahwa dalam sebuah kegiatan pembelajaran, seharusnya siswa dituntun dan dituntut menyelesaikan soal dengan baik, karena salah satu penyebab kesalahan dalam mengerjakan soal (dalam hal ini memetakan masalah sumber dan target) yaitu kurang fokusnya siswa dalam memahami dan memperhatikan soal.

S3 dalam mengerjakan soal memulai dengan menuliskan hal yang telah diketahui terlebih dahulu, hal ini dapat terlihat dari gambar 4. Kemudian S3 kurang tepat dalam membuat pemetaan yang seharusnya menggunakan konsep persegi panjang, tetapi S3 menggunakan konsep volume tabung. Bukan hanya itu, ketika memasuki tahapan applying S3 juga tidak tepat dalam menggunakan variabel yang telah dituliskan sebelumnya, dapat terlihat pada gambar 4 muncul beberapa angka yang tidak terdapat pada langkah sebelumnya, ketika dikonfirmasi melalui sesi wawancara S3 kesulitan untuk menjelaskan karena terindikasi siswa hanya mengarang saja. Hal ini dapat disebabkan kurangnya kemampuan pemahaman konsep siswa yang masih lemah, khususnya dalam menggunakan penalaran analogi, ini sejalan dengan pendapat (Lee \& Sriraman, 2011) menyatakan cara efisiensi dalam membangun sebuah pengetahuan seharusnya dapat dipermudah dengan memperasah dan melatih penalaran analogi melalui pemecahan masalah. 


\section{SIMPULAN}

Analisis data yang telah dihasilkan, diperoleh data penalaran analogi ketiga subjek penelitian dalam memecahkan masalah bangun ruang sisi lengkung. Subjek penelitian pertama S1 merupakan subjek penelitian dengan gaya kognitif berkemampuan tinggi, Subjek penelitian kedua S2 merupakan subjek penelitian dengan gaya kognitif berkemampuan sedang, dan subjek penelitian ketiga S3 merupakan subjek penelitian dengan gaya kognitif berkemampuan rendah. Ketiga subjek tersebut telah memecahkan masalah bangun ruang sisi lengkung.

S1 dan S2 dalam memecahkan soal TPABRSL memulai dengan tahap encoding (mengode) secara jelas sesuai denga hal yang telah diketahui pada soal. Selanjutnya, pada tahap inferring (menyimpulkan) yang dapat terlihat dari kegiatan wawancara, S1 dan S2 dapat melakukan pendugaan yang sesuai dengan semestinya. Pada tahap mapping (memetakan), S1 dapat memetakan unsur sama yang telah ada dan dapat memecahkannya dengan baik, sedangkan perbandingan terbalik terjadi pada S2 yang tidak dapat memetakan dengan baik. Untuk komponen applying (menerapkan), S1 dan S2 memiliki perbedaan. $\mathrm{S} 1$ dapat memilih aturan yang sesuai antara masalah sumber dan masalah target, tetapi sebaliknya S2 tidak dapat menyelesaikan dengan baik karena terjadinya ketidaktepatan pada kesalahan memasukkan hasil pengodean akibat solusi dari masalah sumber tidak terjawab dengan tuntas. Berbeda halnya dengan S3 yang hanya mampu melewati tahap encoding itupun kurang sempurna, sedangkan untuk tahap inferring, tahap mapping, dan tahap applying tidak dapat dilakukan secara benar. Hal tersebut dapat dipengaruhi oleh beberapa faktor, yaitu penguasan konsep yang masih lemah, kurangnya kebiasaan siswa untuk berhati-hati dan fokus dalam menyelesaikan masalah, cenderung terburu-buru, dan kurangnya guru memberikan soal yang bervariasi.

Berdasarkan kesimpulan dari hasil penelitian maka peneliti menyarankan sebagai berikut. Pertama, peneliti lain yang ingin melakukan penelitian serupa terkait dengan proses penalaran analogi hendaknya meneliti pada subjek selain berdasarkan gaya kognitif impulsif seperti gaya kognitif reflektif maupun gaya kognitif yang lainnya. Selain itu, hendaknya dapat meneliti dengan materi selain bangun ruang sisi lengkung. Kedua, subjek dalam penelitian kurang bervariatif dan luas karena subjek yang digunakan untuk penelitian ini siswa SMA. Oleh karena itu, peneliti menyarankan untuk dilakukan penelitian lanjutan yang lebih bervariatif pada siswa SD, SMP, maupun mahasiswa.

\section{DAFTAR RUJUKAN}

BSNP. (2008). Pedoman Penyusuna Kurikulum Tingkat Satuan Pendidikan Jenjang Sekolah Dasar. Jakarta: BSNP.

Callejo, M. L., \& Vila, A. (2009). Approach to Mathematical Problem Solving and Students' Belief Systems: Two Case Studies. Educational Studies in Mathematics, 72(1), 111-126. https://doi.org/10.1007/s10649-009-9195-z

Chrysostomou, M., Pitta-Pantazi, D., Tsingi, C., Cleanthous, E., \& Christou, C. (2013). Examining Number Sense and Algebraic Reasoning Through Cognitive Styles. Educational Studies in Mathematics, 83(2), 205-223. https://doi.org/10.1007/s10649-012-9448-0

Herbert, S. (2009). Professional Learning in Mathematical Reasoning: Reflections of a Primary Teacher. Dalam W. Widjaja, L. A. Bragg, \& Esther (Ed.), Proceddings of the $39^{\text {th }}$ Conferrence of the Mathematics Education Research Group of australasia (hlm. 279-286). Deakin University.

Lailiyah, S., Nusantara, T., Sadijah, C., \& Irawan, E. B. (2017). Developing Student Analogical Reasoning Through Algebraic Problems. Jurnal Pendidikan Sains, 5(2), 38-45.

Lee, K.-H., \& Sriraman, B. (2011). Conjecturing Via Reconceived Classical Analogy. Educational Studies in Mathematics, 76(2), 123-140. https://doi.org/10.1007/s10649-010-9274-1

Mason, L. (1994). Cognitive and Metacognitive Aspects in Conceptual Change by Analogy. Instructional Science, 22 , $157-187$.

Mikrayanti. (2012). Meningkatkan Kemampuan Penalaran dan Komunikasi Matematis Siswa Menengan Atas melalui Pembelajaran Berbasis Masalah (Studi Kuasi Eksperimen pada Siswa SMA di Kabupaten Bima. Tesis tidak diterbitkan. Universitas Pendidikan Indonesia, Bandung.

Mofidi, S. A., Amiripour, P., \& Zadeh, M. H. B. (2012). Instruction of Mathematical Concept Through Analogical Reasoning Skills. Indian Journal of Science and Technology, 5(6), 2916-2922.

Moleong, L. J. (2011). Metode Penelitian Kualitatif. Bandung: PT. Remaja Rosdakarya.

National Council of Teachers of Mathematics (Ed.). (2000). Principles and Standards for School Mathematics. Reston, VA: National Council of Teachers of Mathematics.

Ozerem, A. (2012). Misconceptions in Geometry and Suggested Solutions for Seventh Grade Student. International Journal of New Trends in Arts, 1(4), 23-35.

Pang, Alawyn, W.-K., \& Dindyal, J. (2009). Analogical Reasoning Errors in Mathematics at Junior College Level. Proceedings of the $32^{\text {nd }}$ Annual Conference of the Mathematics Education Research Group of Australasia, 1, 1-8. Nanyang Technological University.

PISA. (2015). Results: What Student Know and Can Do Student Performance in Mathematics, Reading and Science.

Rahman. (2018). Analisis Hasil Belajar Matematika Berdasarkan Perbedaan Gaya Kognitif secara Psikologis dan Konseptual Tempo pada Siswa Kelas X SMA Negeri 3 Makasar. Jurnal Pendidikan dan Kebudayaan, 14(72).

Romadlona, A. F., Parta, I. N., \& Dwiyana. (2018). Penalaran Analogi Siswa Reflektif Kelas X dalam Menyelesaikan Soal Trigonometri. Jurnal Pendidikan: Teori, Penelitian, dan Pengembangan, 3(1), 1-8. 
Rozencwajg, P. (2003). Metacognitive Factors in Scientific Problem Solving Strategies. European Journal of Psychology of Education, 3(18), 281-294.

Rozencwajg, P., \& Corroyer, D. (2005). Cognitive Processes in the Reflective-Impulsive Cognitive Style. The Journal of Genetic Psychology, 166(4), 451-463. 